\title{
Claudio Monteverdi:
}

\section{L'ORFEO \\ FAVOLA IN MUSICA}

\section{ORFEO \\ A TALE IN MUSIC}

\author{
Italian Libretto \\ by Alessandro Striggio \\ and \\ English Translation \\ by Gilbert Blin
}

This libretto of L'Orfeo is mostly copied from the 1615 edition of Monteverdi's score (second printed edition).

One of the first known editions of the libretto has also been consulted as a reference for spelling, punctuation and lineation of versification: La Favola d'Orfeo rappresentata in musica II Carnevale dell'Anno MDCVII Nell'Accademia de gl'Invaghiti di Mantova; Sotto I felici auspizij del Sereniss. Sig. DUCA benignissimo lor proterrore. In MANTOVA, per Francesco Osanna Stampator Ducale. 1607. Con licenza de'Superiori.

This edition is, in academic opinion, closer to the text that Monteverdi had to hand when composing the music, although it is simply printed and contains a different ending to Act $V$ as compared with the 1609 and 1615 scores.

The disposition of capital letters in the Italian edition, used to attract the attention of the reader to a specfic word, has been respected in the formatting of the translation, as it is also considered informative today.

Spelling has been sometimes modernized and capitalization of words, punctuation, and lineation - notably the entire end of Act $V$ (text missing in Striggio) - are editorial.

The translation of the libretto follows as much as possible the rhetorical order of the verses of the original Italian text. I would like to thank Andrew Sigel, my editor, for his precious help and advice. 
PERSONAGGI

La Musica

Orfeo

Euridice

Ninfe e Pastori

Speranza

Caronte

Spiriti Infernali

Proserpina

Plutone

Eco

Apollo
CHARACTERS

Music

Orfeo (Orpheus)

Euridice (Eurydice)

Nymphs and Shepherds

Hope

Caronte (Charon)

Infernal Spirits

Proserpina

Plutone (Pluto)

Echo

Apollo

\section{PROLOGO}

\section{La Musica}

Dal mio Permesso amato à voi ne vegno, Incliti Eroi, sangue gentil de' Regi, Di cui narra la Fama eccelsi pregi, Nè giunge al ver, perch'è tropp' alto il segno.

Io la Musica son, ch'a i dolci accenti, Sò far tranquillo ogni turbato core, Ed hor di nobil ira, \& hor d'amore Posso infiammar le più gelate menti.

lo sù Cetera d'or cantando soglio Mortal orecchio lusingar talhora, $E$ in questa guisa a l'armonia sonora De la lira del Ciel più l'alme invoglio;

Quinci à dirvi d'ORFEO desio mi sprona, D'ORFEO che trasse al suo cantar le fere, E servo fè I'Inferno a sue preghiere, Gloria immortal di Pindo e d'Elicona.

Hor mentre i canti alterno hor lieti, hor mesti, Non si mova augellin fra queste piante, Nè s'oda in queste rive onda sonante, Ed ogni auretta in suo cammin s'arresti.

\section{PROLOGUE}

\section{Music}

From my beloved Permessus I come to you, Glorious Heroes, noble bloodline of Rulers, Of whom Fame relates high praise Without quite attaining the truth, as it is too high a mark.

I am Music, who in sweet accents, Can make peaceful every troubled heart, And so with noble anger, and so with love, Can I inflame the coldest minds.

Singing with my golden Lyre, I like To charm, now and then, mortal ears, And in such a fashion that I make their souls aspire more For the resounding harmony of the lyre of Heaven.

Hence desire spurs me to tell you of ORFEO:

Of ORFEO who tamed wild beasts with his song And made Hades answer his prayers, To the immortal glory of Pindus and Helicon.

While I vary my songs, now happy, now sad, No small bird shall move among these bushes, Nor on these banks a sounding wave be heard, And every breeze shall stay its wanderings. 


\section{ATTO PRIMO}

\section{Pastore}

In questo lieto e fortunato giorno,

Ch'ha posto fine à gli amorosi affanni

Del nostro Semideo, cantiam Pastori,

In sì soavi accenti,

Che sian degni d'ORFEO nostri concenti.

Oggi fatt'è pietosa

L'alma già si sdegnosa

De la bella EURIDICE.

Oggi fatt'è felice

ORFEO nel sen di lei, per cui già tanto

Per queste selve hà sospirato, e pianto.

Dunque in si lieto e fortunato giorno

Ch'ha posto fine a gli amorosi affanni

Del nostro Semideo, cantiam Pastori,

In si soavi accenti,

Che sian degni d'ORFEO nostri concenti.

\section{Coro}

Vieni, Imeneo, deh, vieni,

E la tua face ardente

Sia quasi un sol nascente

Ch'apporti a questi amanti i dì sereni,

E lunge homai disgombre

Degli affanni e del duol gli orrori e l'ombre.

\section{Ninfa}

Muse, honor di Parnaso, amor del Cielo,

Gentil conforto à sconsolato core,

Vostre cetre sonore

Squarcino d'ogni nube il fosco velo;

E mentre oggi propizio al nostro ORFEO

Invochiam Imeneo

Su ben temprate corde,

Sia il vostro canto al nostro suon concorde.

\section{Shepherd}

On this happy and auspicious day

Which ends the amorous torments

Of our Demigod, let us sing, Shepherds,

With sweet accents,

May our singing be worthy of ORFEO.

Today has made merciful

The formerly disdainful soul

Of fair EURIDICE.

Today has made happy

ORFEO in the bosom of her for whom he once

Sighed and wept throughout these woods.

Thus on such a happy and auspicious day

Which ends the amorous torments

Of our Demigod, let us sing, Shepherds,

With sweet accents,

May our singing be worthy of ORFEO.

\section{Chorus}

Come, Hymen, do come,

And may your ardent torch

Be like a rising sun

That brings these lovers peaceful days

And forever banish

The horrors and shadows of torments and grief.

\section{Nymph}

Muses, honour of Parnassus, love of Heaven, Gentle comfort to the disconsolate heart, The music of your lyres

Tears apart the dark veil of every cloud:

And while today, to favor our ORFEO,

We call to Hymen

On well-tempered strings,

Let our music tune with your song.

Please turn page quietly 


\section{Choro}

Lasciate i monti,

Lasciate i fonti,

Ninfe vezzos'e liete,

$E$ in questi prati

Ai balli usati

Vago il bel piè rendete.

Qui miri il sole

Vostre carole,

Più vaghe assai di quelle,

Ond'à la Luna,

La notte bruna,

Danzano in Ciel le stelle.

Lasciate i monti,

lasciate i fonti,

Ninfe vezzos'e liete,

$E$ in questi prati

ai balli usati

Vago il bel piè rendete.

Poi di bei fiori

Per voi s'honori

Di questi amanti il crine,

Ch'or de i martiri

De i lor desiri

Godon beati al fine.

\section{Pastore}

Ma tu gentil cantor s'à tuoi lamenti

Già festi lagrimar queste campagne,

Perc'hor al suon della famosa cetra

Non fai teco gioir le valli e i poggi?

Sia testimon del core

Qualche lieta canzon che detti Amore.

\section{Orfeo}

Rosa del Ciel, vita del mondo, e degna

Prole di lui che I'Universo affrena.

Sol che'l tutto circondi e'l tutto miri,

Dagli stellanti giri,

Dimmi, vedestù mai

Di me più lieto e fortunato amante?

Fù ben felice il giorno,

Mio ben, che pria ti vidi,

E più felice l'ora

Che per te sospirai,

Poich'al mio sospirar tu sospirasti:

Felicissimo il punto

Che la candida mano,

Pegno di pura fede à me porgesti.

\section{Chorus}

Leave the mountains, Leave the fountains,

Lovely and joyful Nymphs.

And in these meadows

To the traditional dances

Let your fair feet rejoice.

Here the sun beholds

Your dancing,

More lovely than

When, for the moon

In the dark night,

The stars themselves dance in Heaven.

Leave the mountains,

Leave the fountains,

Lovely and joyful Nymphs.

And in these meadows

To the traditional dances

Let your fair feet rejoice.

Then with fine flowers

Be ready to honour

These lovers' heads,

That after suffering

They may happily

Enjoy their desires at last.

\section{Shepherd}

But you, gentle singer, whose laments

Once made these fields weep,

Why not now, to the sound of your famous lyre,

Make the valleys and hills rejoice?

Let the witness of your heart be

Some happy song inspired by Love.

\section{Orfeo}

Rose of heaven, life of the world, and worthy

Heir of him who holds the Universe in sway:

O Sun, who encircles all and sees all

From your starry orbits,

Tell me, have you ever seen

A happier and more fortunate lover than I?

So happy was the day,

My love, when first I saw you,

And happier the hour

When I sighed for you,

Because at my sighs you sighed:

Happiest the moment

When your white hand,

Pledge of pure faith, you gave to me. 
Se tanti Cori havessi

Quant' occh'hà il Ciel eterno, e quante chiome

Han questi Colli ameni il verde maggio,

Tutti colmi sarieno e traboccanti

Di quel piacer ch'oggi mi fà contento.

\section{Euridice}

lo non dirò qual sia

Nel tuo gioire ORFEO la gioia mia,

Che non hò meco il core,

Ma teco stassi in compagnia d'Amore;

Chiedilo dunque a lui, s'intender brami

Quanto lieta gioisca, e quanto t'ami.

\section{Choro}

\author{
Lasciate i monti, \\ Lasciate i fonti, \\ Ninfe vezzos'e liete, \\ $\mathrm{E}$ in questi prati \\ ai balli usati \\ Vago il bel piè rendete. \\ Qui miri il sole \\ Vostre carole, \\ Più vaghe assai di quelle, \\ Ond'à la Luna, \\ La notte bruna, \\ Danzano in Ciel le stelle.
}

\section{Choro}

Vieni, Imeneo, deh, vieni,

E la tua face ardente

Sia quasi un sol nascente

Ch'apporti a questi amanti i dì sereni,

E lunge homai disgombre

Degli affanni e del duol gli orrori e l'ombre.

\section{Pastore}

Ma s'il nostro gioir dal Ciel deriva

Com'è dal Ciel ciò che qua giù n'incontra,

Giusto è ben che devoti

Gli offriam incensi e voti.

Dunque al Tempio ciascun rivolga i passi

A pregar lui nella cui destra è il Mondo,

Che lungamente il nostro ben conservi.
If I had as many Hearts

As eternal Heaven has eyes and as these

Lovely Hills in green May have leaves,

They would all be brimming and overflowing

With that pleasure that today makes me content.

\section{Euridice}

I will not say that

In your joy, ORFEO, is my joy,

For no longer do I possess my own heart.

It is with you in the company of Love;

Ask of it, then, if you want to know

How happily it rejoices, and how much it loves you.

\section{Chorus}

Leave the mountains,

Leave the fountains,

Lovely and joyful Nymphs.

And in these meadows

To the traditional dances

Let your fair feet rejoice.

Here the sun beholds

Your dancing,

More lovely than

When, for the moon

In the dark night,

The stars themselves dance in Heaven.

\section{Chorus}

Come, Hymen, do come,

And may your ardent torch

Be like a rising sun

That brings these lovers peaceful days

And forever banish

The horrors and shadows of torments and grief.

\section{Shepherd}

But if our joy derives from Heaven,

As from Heaven comes all that happens down here,

It is right and fair that we should devoutly

Offer incense and prayers.

So to the Temple let us turn our steps

To pray to him in whose right hand is the World,

That he may long keep us well.

Please turn page quietly 


\section{Choro}

Alcun non sia che disperato in preda Si doni al duol, benchè talhor n'assaglia Possente sì che nostra vita inforsa. Che poiche nembo rio gravido il seno D'atra tempesta inorridito hà il Mondo, Dispiega il Sol più chiaro i rai lucenti.

E dopò l'aspro gel del Verno ignudo Veste di fior la Primavera i campi. Ecco ORFEO, cui pur dianzi

Furon cibo i sospir, bevanda il pianto. Oggi felice è tanto

Che nulla è più che da bramar gli avanzi.

\section{Chorus}

Let none be victim of despair

Or sorrow, though they assail us In strength and threaten our life.

For, after the sudden storm and great flood

At the heart of a black tempest that has terrified the World, The Sun more brightly displays its luminous rays.

And after the harsh frost of naked Winter Spring clothes the meadows with flowers. Here is ORFEO, for whom Sighs had been food, and the tears drink. Today he is so happy

That there is nothing more for him to wish for. 


\section{Orfeo}

Ecco pur ch'à voi ritorno,

Care selve e piagge amate,

Da quel Sol fatte beate

Per cui sol mie notti han giorno.

\section{Pastore}

Mira ch'à sè n'alletta

L'ombra ORFEO di que' faggi,

Or che infocati raggi

Febo dal Ciel saetta.

Sù quelle erbose sponde

Posianci, e in vari modi

Ciascun sua voce snodi

Al mormorio de l'onde.

\section{Due pastori}

In questo prato adorno

Ogni selvaggio Nume

Sovente hà per costume

Di far lieto soggiorno.

Qui Pan Dio de' Pastori,

S'udi talor dolente

Rimembrar dolcemente

Suoi sventurati amori.

\section{Due pastori}

Qui le Napèe vezzose,

(Schiera sempre fiorita)

Con le candide dita

Fu viste à coglier rose.

\section{Choro}

Dunque fa degni, ORFEO,

Del suon de la tua lira

Questi campi, ove spira

Aura d'odor sabèo.

\section{Orfeo}

Here I return to you,

Dear forests and beloved meadows,

Blessed by that very Sun

Through whom alone my nights are day.

\section{Shepherd}

See, how here we are enticed by

The shade, ORFEO, of these beech trees,

Now that Phoebus shoots his burning rays

Down from Heaven.

On these grassy banks

Let us sit, and in various modes

Each free his voice

To the murmuring of the waters.

\section{Two Shepherds}

In this flowery meadow

Every woodland God

Oftentimes, by custom,

Makes his merry sojourn.

Here Pan, God of Shepherds,

Is heard sometimes sorrowing

Remembering sweetly

His unlucky loves.

\section{Two Shepherds}

Here charming wood Nymphs

(Always adorned with flowers)

With white fingers

Were seen picking roses.

\section{Chorus}

Then, ORFEO, honour

With the sound of your lyre

These fields where breathes

The perfume of Sheba. 


\section{Orfeo}

Vi ricorda ò bosch'ombrosi

De'miei lunghi aspri tormenti,

Quando i sassi à' miei lamenti

Rispondean fatti pietosi?

Dite: allhor non vi sembrai

Più d'ogni altro sconsolato?

Hor fortuna ha stil cangiato

Ed hà volti in festa i guai.

Vissi già mesto e dolente;

Or gioisco, e quegli affanni

Che sofferti hò per tant'anni

Fan più caro il ben presente.

Sol per tè, bella EURIDICE,

Benedico il mio tormento;

Dopo il duol viè più contento,

Dopo il mal viè più felice.

\section{Pastore}

Mira, deh mira, ORFEO, che d'ogni intorno

Ride il bosco e ride il prato,

Segui pur co'l plettro aurato

D'addolcir l'aria in si beato giorno.

\section{Messaggiera}

Ahi caso acerbo, ahi fato empio e crudele, Ahi stelle ingiuriose, ahi Cielo avaro.

\section{Pastore}

Qual suon dolente il lieto dì perturba?

\section{Messaggiera}

Lassa, dunque debb'io,

Mentre ORFEO con sue note il ciel consola,

Con le parole mie passargli il core?

\section{Pastore}

Questa è Silvia gentile,

Dolcissima compagna

De la bella EURIDICE: ò quanto è in vista

Dolorosa: hor che fia? deh sommi Dei,

Non torcete da noi benigno il guardo.

\section{Messaggiera}

Pastor, lasciate il canto,

Ch'ogni nostra allegrezza in doglia è volta.

\section{Orfeo}

Do you remember, $\mathrm{O}$ shady groves,

My long and harsh torments,

When, at my laments, the rocks

Were moved to pity?

Say, did I not seem to you

More wretched than any other?

Now fortune has changed her course

And has turned woes into joy.

I lived then in sadness and sorrow,

Now I rejoice, and those torments

That I suffered for so long

Make my present happiness much dearer.

Only for you, fair EURIDICE,

I bless my torment;

After sorrow one is even more content, After woe, one is even happier.

\section{Shepherd}

See, ah see, ORFEO, how at every turn

The woods laugh and the meadow laughs;

Continue with your plectrum of gold

To sweeten the air of such a blessed day.

\section{Messenger}

Ah bitter fate, ah wicked and cruel destiny, Ah hurtful stars, ah avaricious Heaven.

\section{Shepherd}

What mournful sound disturbs the happy day?

\section{Messenger}

Alas, then must I,

While ORFEO with his music comforts heaven,

With my words pierce his heart?

\section{Shepherd}

This one is gentle Silvia,

Sweetest companion

Of fair EURIDICE: oh, how sad she looks:

What has happened? Ah, Gods above,

Do not turn your kind eye away from us.

\section{Messenger}

Shepherds, leave your singing,

For all our good cheer is turned to pain. 


\section{Orfeo}

Donde vieni? ove vai?

Ninfa che porti?

\section{Messaggiera}

A te ne vengo ORFEO,

Messaggiera infelice

Di caso più infelice e più funesto.

La tua bella EURIDICE...

\section{Orfeo}

Ohimè che odo?

\section{Messaggiera}

La tua diletta sposa è morta.

\section{Orfeo}

Ohimè.

\section{Messaggiera}

In un fiorito prato

Con l'altre sue compagne

Giva cogliendo fiori

Per farne una ghirlanda alle sue chiome,

Quand'angue insidioso,

Ch'era fra l'erbe ascoso,

Le punse un piè con velenoso dente,

Ed ecco immantinente

Scolorirsi il bel viso e ne' suoi lumi

Sparir que' lampi, ond'ella al Sol fea scorno.

Allor, noi tutte sbigottite e meste

Le fummo intorno, richiamar tentando

Gli spiriti in lei smarriti

Con l'onda fresca e co' possenti carmi;

Ma nulla valse, ahi lassa,

Ch'ella i languidi lumi alquanto aprendo

E te chiamando, ORFEO,

Dopò un grave sospiro

Spirò fra queste braccia; ed io rimasi

Piena il cor di pietade e di spavento.

\section{Pastore}

Ahi, caso acerbo, ahi fato empio e crudele, Ahi stelle ingiuriose, ahi Cielo avaro.

\section{Orfeo}

Where do you come from? Where are you going?

Nymph, what do you bring?

\section{Messenger}

To you I come, ORFEO,

Unhappy messenger

With tidings more unhappy and more baleful.

Your fair EURIDICE...

\section{Orfeo}

Alas, what do I hear?

\section{Messenger}

Your beloved spouse is dead.

\section{Orfeo}

Alas.

\section{Messenger}

In a flowery meadow

With her other companions

She went picking flowers

To make a garland for her hair,

When a deceitful snake

That was hidden in the grass,

Bit her foot with poisoned fangs.

And immediately

Her fair face grew pale and in her eyes

That light that outshone the Sun faded.

Then we all, appalled and sorrowed,

Gathered around her, trying to call back

The spirits that grew faint in her,

With fresh water and with powerful charms,

But to no avail, ah alas,

For she opened her failing eyes a little,

And calling you, ORFEO,

After a deep sigh,

She died in these arms; and I was left,

My heart filled with pity and horror.

\section{Shepherd}

Ah bitter fate, ah wicked and cruel destiny, Ah hurtful stars, ah avaricious Heaven.

Please turn page quietly 


\section{Pastore}

A l'amara novella

Rassembra l'infelice un muto sasso

Che per troppo dolor non può dolersi.

\section{Pastore}

Ahi ben havrebbe un cor di Tigre o d'Orsa

Chi non sentisse del tuo mal pietade

Privo d'ogni tuo ben, misero amante.

\section{Orfeo}

Tu se' morta, mia vita, ed io respiro?

Tu se' da me partita

Per mai più non tornare, ed io rimango?

No, che se i versi alcuna cosa ponno, N'andrò sicuro a' più profondi abissi, $E$, intenerito il cor del Ré de l'ombre, Meco trarrotti a riveder le stelle:

$\mathrm{O}$, se ciò negherammi empio destino, Rimarrò teco in compagnia di morte. A dio, terra, à dio Cielo, e Sole à dio.

\section{Choro}

Ahi caso acerbo, ahi fato empio e crudele.

Ahi stelle ingiuriose, ahi Cielo avaro.

Non si fidi huom mortale

Di ben caduco e frale,

Che tosto fugge, e spesso

A gran salita il precipizio è presso.

\section{Messaggiera}

Ma io ch' in questa lingua

Hò portato il coltello

C'hà svenata d'ORFEO l'anima amante,

Odiosa à i Pastori \& à le Ninfe,

Odiosa à me stessa, ove m'ascondo?

Nottola infausta il Sole

Fuggirò sempre, e in solitario speco

Menerò vita al mio dolor conforme.

\section{Shepherd}

At the bitter news

The unhappy man seems like a speechless statue

Who with too much grief cannot grieve.

\section{Shepherd}

Ah, he would have the heart of a Tiger or a Bear

Who did not feel pity at your misfortune,

Deprived of your beloved, wretched lover.

\section{Orfeo}

You are dead, my life, and I still breathe?

You are gone from me

Never to return, and I should remain?

No, for if verses can do anything,

I will go in safety to the deepest abysses,

And having softened the heart of the King of shades,

I will bring you back with me to see the stars again:

Oh, if wicked destiny refuses me this,

I will stay with you, in the company of death.

Farewell earth, farewell Heaven and Sun, farewell.

\section{Chorus}

Ah bitter fate, ah wicked and cruel destiny,

Ah hurtful stars, ah avaricious Heaven.

Let no mortal man trust

Fleeting and frail happiness,

That soon vanishes, and often

After a great ascent a precipice is near.

\section{Messenger}

But I who with these words

Have brought the knife

That has slain the loving soul of ORFEO,

Hateful to the Shepherds and to the Nymphs,

Hateful to myself, where may I hide?

Like an ill-omened bat, I will forever flee the Sun, and in a lonely cavern

Will lead a life that matches my grief. 


\section{Choro}

Chi ne consola ahi lassi?

O pur, chi ne concede

Negli occhi un vivo fonte

Da poter lagrimar come conviensi

In questo mesto giorno,

Quanto più lieto già tant'hor più mesto?

Oggi turbo crudele

I due lumi maggiori

Di queste nostre selve,

EURIDICE, \& ORFEO,

L'una punta da l'angue

L'altro dal duol trafitto, ahi, lassi, hà spenti.

Ahi caso acerbo, ahi fato empio e crudele, Ahi stelle ingiuriose, ahi Cielo avaro.

Ma dove, ah dove hor sono

De la misera Ninfa

Le belle e fredde membra,

Dove suo degno albergo

Quella bell'alma elesse,

Ch'oggi è partita in su'l fiorir de' giorni?

Andiam Pastori andiamo

Pietosi a ritrovarle,

E di lagrime amare

II dovuto tributo

Per noi si paghi almeno al corpo esangue.

Ahi caso acerbo, ahi fato empio e crudele, Ahi stelle ingiuriose, ahi Cielo avaro.

Qui si muta la Scena.

\section{Chorus}

Who will console us, ah, alas?

Or rather, who will grant

In our eyes a living fountain

That we may cry as we should

On this most mournful day,

All the more mournful because once so happy?

Today a cruel darkness

The two greater lights

Of these our woods -

EURIDICE and ORFEO,

One bitten by a snake,

The other pierced by grief - ah, alas, has quenched.

Ah bitter fate, ah wicked and cruel destiny,

Ah hurtful stars, ah avaricious Heaven.

But where, ah, where now are

The wretched Nymph's

Lovely, cold limbs,

Where is the worthy dwelling

That her fair soul chose,

Who today has departed in the flower of her days?

Let us go, Shepherds, let us go

With compassion to find her

And with bitter tears

The rightful tribute

Shall at least be paid to her lifeless body.

Ah bitter fate, ah wicked and cruel destiny,

Ah hurtful stars, ah avaricious Heaven.

Here the set is changed.
Il fine del secondo Atto.
End of the second Act. 


\section{Orfeo}

Scorto da te, mio Nume

Speranza unico bene

De gli afflitti mortali, omai son giunto

A questi mesti e tenebrosi regni,

Ove raggio di Sol giammai non giunse.

$\mathrm{Tu}$, mia compagna e duce

In così strane e sconosciute vie,

Reggesti il passo debole e tremante,

Ond'oggi ancora spero

Di riveder quelle beate luci

Che sol'à gli occhi miei portan il giorno.

\section{Speranza}

Ecco l'atra palude, ecco il nocchiero Che trahe gl'ignudi spirti a l'altra riva, Dove hà Pluton de l'ombre il vasto impero.

Oltre quel nero stagno, oltre quel fiume, In quei campi di pianto e di dolore, Destin crudele ogni tuo ben t'asconde.

Or d'uopo è d'un gran core e d'un bel canto.

lo sin qui ti hò condotto, or più non lice

Teco venir, ch'amara legge il vieta,

Legge scritta co'l ferro in duro sasso

De l'ima reggia in su l'orribil soglia,

$\mathrm{Ch}^{\prime}$ in queste note il fiero senso esprime:

LASCIATE OGNI SPERANZA Ò VOI CH'ENTRATE

Dunque, se stabilito hai pur nel core

Di porre il piè nella Città dolente,

Da te me'n fuggo e torno

A l'usato soggiorno.

\section{Orfeo}

Dove, ah, dove te'n vai, Unico del mio cor dolce conforto?

Poichè non lunge homai

Del mio lungo camin si scopre il porto,

Perchè ti parti e m'abbandoni, ahi, lasso,

Sul periglioso passo?

Qual bene hor più m'avanza

Se fuggi tù, dolcissima Speranza?

\section{Orfeo}

Escorted by you, my Deity,

Hope, only solace

Given the afflicted mortals, now I have arrived

At these mournful and dark realms

Where a Sun's ray can find no entrance.

You, my companion and guide

On paths so unwonted and unknown

Have directed my feeble, trembling steps,

Where today I still hope

To see once more those blessed eyes

That alone can bring light to mine.

\section{Hope}

Here is the dark marsh, here the boatman

Who ferries naked souls to the other bank,

Where Plutone rules his vast empire of shades.

Beyond that black swamp, beyond that river,

In those fields of tears and sorrow,

Cruel destiny hides your beloved.

You now need to have a brave heart and a fair song.

I have brought you here, but further I may not

Come with you, for harsh law forbids it,

A law written with iron on hard stone

At the dreaded entrance to the kingdom below,

That in these words expresses its terrible meaning:

ABANDON ALL HOPE, YOU WHO ENTER.

Therefore, if your heart is determined

To set foot in the City of grief,

I must flee from you and return

To my accustomed adobe.

\section{Orfeo}

Where, ah, where are you going,

Only sweet comfort of my heart?

Now that, at last,

The destination of my long journey appears nearby,

Why do you leave and abandon me, ah, alas,

On this perilous path?

What good now remains for me

If you flee, sweetest Hope? 


\section{Caronte}

O tu ch'innanzi morte a queste rive

Temerario ten vieni, arresta i passi:

Solcar quest'onde ad huom mortal non dassi, Ne può co'morti albergo aver chi vive.

Che? Vuoi forse, nemico al mio Signore,

Cerbero trar dalle Tartaree porte?

O rapir brami sua cara consorte

D'impudico desire acceso il core?

Pon freno al folle ardir, ch' entr' al mio legno

Non accorrò più mai corporea salma,

Sì de gli antichi oltraggi ancor ne l'alma

Serbo acerba memoria e giusto sdegno.

\section{Orfeo}

Possente Spirto, e formidabil Nume, Senza cui far passaggio a l'altra riva Alma da corpo sciolta in van presume; Non viv' io, nò, che poi di vita è priva Mia cara sposa, il cor non è più meco E senza cor com' esser può ch'io viva? A lei volt' ho il cammin per l'aer cieco, A I'Inferno non già, ch'ovunque stassi Tanta bellezza, il Paradiso ha seco. ORFEO son io, che d'EURIDICE i passi

Seguo per queste tenebrose arene, Ove giammai per huom mortal non vassi. O delle luci mie luci serene, S'un vostro sguardo può tornarmi in vita, Ahi, chi niega il conforto à le mie pene? Sol tuo, nobile Dio, puoi darmi aita, Nè temer dei, che sopra una aurea Cetra Sol di corde soavi armo le dita Contra cui rigid' alma in van s'impetra.

\section{Caronte}

Ben mi lusinga alquanto

Dilettandomi il core, Sconsolato Cantore, Il tuo piantí e 'I tuo canto. Ma lunge, ah lunge sia da questo petto Pietà, di mio valor non degno effetto.

\section{Caronte}

O you who, before death, rashly come

To these shores, halt your steps:

To cross these waves is not granted to mortal man, Nor can he who lives dwell with the dead.

What? Perhaps you, as enemy to my Lord,

Want to drag Cerberus from the Tartarean gates?

Or wish to ravish his dear consort,

Your heart on fire with lewd desire?

Restrain your foolish audacity, for into my boat

Shall a living body never again enter:

Of the ancient outrages still in my soul

I keep bitter memory and just anger.

\section{Orfeo}

Powerful Spirit and fear-inspiring God, Without whom to make passage to the other bank A soul, freed from the body, presumes in vain:

I do not live, no; since my dear bride Was deprived of life, my heart is no longer with me, And without a heart how can it be that I live? For her I have made my way through the blind air, Not yet to Hades, for wherever there is Such beauty there is Paradise in her company. ORFEO am I, who follows EURIDICE's steps

On these dark sands, Where never mortal man has gone.

O serene light of my eyes, If one look of yours can return me to life, Ah, who denies comfort to my afflictions? You alone, noble God, can help me, Nor should you fear, since on a golden Lyre My fingers are only armed with sweet strings, Against which the merciless soul tries in vain to resist.

\section{Caronte}

Indeed you charm me,

Appeasing my heart,

Disconsolate Singer,

With your plaints and your song.

But far, ah, far from this breast

Lies pity, an effect unworthy of my valour.

Please turn page quietly 


\section{Orfeo}

Ahi sventurato amante,

Sperar dunque non lice

Ch'odan miei prieghi i Cittadin d'Averno?

Onde qual' ombra errante

D'insepolto cadavero e infelice,

Privo sarò del Ciel e de I'Inferno?

Così vuol empia sorte

Ch'in quest' orror di morte

Da te cor mio lontano

Chiami tuo nome in vano,

E pregando, e piangendo io mi consumi?

Rendetemi'I mio ben, Tartarei Numi.

Ei dorme, e la mia cetra

Se pietà non impetra

Ne l'indurato core, almen il sonno

Fuggir al mio cantar gli occhi non ponno.

Sù dunque, à che più tardo?

Tempo è ben d'approdar su l'altra sponda, S'alcun non è ch' il neghi.

Vaglia l'ardir se foran vani i prieghi.

E' vago fior del Tempo

L'occasion, ch'esser dèe colta à tempo.

Qui entra nella barca e passa cantando

Mentre versan quest' occhi amari fiumi, Rendetemi il mio ben, Tartarei Numi.

\section{Coro di Spiriti Infernali}

Nulla impresa per uom si tenta invano

Nè contr' a lui più sa natura armarse.

Ei de l'instabil piano

Arò gli ondosi campi, e 'I seme sparse

Di sue fatiche, ond' aurea messe accolse.

Quinci, perchè memoria

Vivesse di sua gloria,

La fama a dir di lui sua lingua sciolse,

Ch'ei pose freno al mar con fragil legno

Che sprezzò d'Austro e d'Aquilon lo sdegno.

\section{Orfeo}

Alas, unhappy lover,

Then may I not hope

That the Citizens of Avernus may hear my prayers?

Then must I, like an errant shade

Of an unhappy, unburied body,

Bereft of Heaven and of Hell?

So does wicked fate desire

That in this horror of death,

My heart, I should from afar

Call your name in vain,

And praying and weeping wear myself away?

Give me back what is mine, Gods of Tartarus.

He sleeps and my lyre,

If it cannot engrave pity

In that hardened heart, at least

His eyes cannot escape slumber from my singing.

So, then, why wait any longer?

It is time to approach the other bank,

If there is no one to forbid it.

Let courage prevail as my prayers were in vain.

A fleeting flower of Time is

The opportunity that must be picked on time.

Here he enters the boat and crosses over, singing

So long as these eyes pour out bitter streams of tears,

Give me back what is mine, Gods of Tartarus.

\section{Chorus of Infernal Spirits}

No undertaking by man is attempted in vain,

Nor against him can Nature further arm herself.

And of the unstable plains

He has ploughed the wavy fields, and scattered the seeds

Of his labours, whence he has gathered golden harvests.

Thus, as memory

Might live of his glory,

Fame, to speak of him, has loosened her tongue,

He who restrained the sea while in a fragile barque,

Who disdained the wrath of the South and North Winds. 


\section{ATTO QUARTO}

\section{Proserpina}

Signor, quell'infelice

Che per queste di morte aspre campagne

Va chiamando EURIDICE,

Ch'udito hai tù pur dianzi

Così soavemente lamentarsi,

Moss'hà tanta pietà dentro al mio core

Ch'un'altra volta torno a porger prieghi

Perchè il tuo Nume al suo pregar si pieghi.

Deh se da queste luci

Amorosa dolcezza unqua trahesti,

Se ti piacque il seren di questa fronte

Che tu chiami tuo Cielo, onde mi giuri

Di non invidiar sua sorte a Giove,

Pregoti per quel foco

Con cui già la grand'alma Amor t'accese.

Fa ch'EURIDICE torni

A goder di quei giorni

Che trar solea vivend' in fest' e in canto,

E del miser' ORFEO consola il pianto.

\section{Plutone}

Benche severo \& immutabil fato

Contrasti amata sposa i tuoi desiri,

Pur nulla homai si nieghi

A tal beltà, congiunta a tanti prieghi.

La sua cara EURIDICE

Contra I'ordin fatale ORFEO ricovri,

Ma pria che tragga il piè da questi abissi,

Non mai volga ver lei gli avidi lumi,

Che di perdita eterna

Gli sia certa cagion un solo sguardo.

lo così stabilisco. Hor nel mio Regno

Fate, ò Ministri, il mio voler palese,

Sì che l'intenda ORFEO

E I'intenda EURIDICE

Ne di cangiar l'altrui sperar più lice.

\section{Choro di Spiriti Infernali}

O de gli habitator de l'ombre eterne

Possente Rè, legge ne fia tuo cenno,

Che ricercar altre cagioni interne

Di tuo voler nostri pensier non denno.

Trarrà da queste orribili caverne

Sua sposa ORFEO, s'adoprerà suo senno

Si che no'l vinca giovanil desio,

Nè i gravi imperi tuoi sparga d'oblio.

\section{Proserpina}

Lord, that unfortunate man,

Who through these rugged fields of death

Goes calling for EURIDICE,

Whom you have just heard

So sweetly lamenting,

Has moved my heart to such pity

That once more I turn to pray

That your spirit will yield to his pleading.

Ah, if from these eyes

You have ever taken loving sweetness,

If the fairness of this brow has pleased you

That you call your Heaven, on which you swear to me

Not to envy Jove his lot,

I beg you, by that fire

With which Love kindled your great soul.

Let EURIDICE return

To enjoy those days

Which she used to pass, living in festivities and in song,

And console the weeping of wretched ORFEO.

\section{Plutone}

Although severe and immutable fate

Is against your desires, beloved wife,

Nothing ever can be refused

Such beauty, together with such prayers.

His dear EURIDICE,

Against the command of fate, ORFEO may recover.

But before he draws away from these abysses

He must never turn his desirous eyes to see her,

Since her eternal loss

Will be caused by a single glance.

So I do command. Now in my Kingdom,

Officers, make known my will,

So that ORFEO may understand it

And EURIDICE understand it,

Nor may anyone hope to change the decree.

\section{Chorus of Infernal Spirits}

For those dwellers in eternal shadows,

Powerful King, let your order be law,

Our thoughts must not seek

Other inmost reasons for your will.

While through these terrible caverns

ORFEO will lead his bride, he will use his judgment

If he is not overcome by youthful desire,

Nor forgets your solemn imperial orders.

Please turn page quietly 


\section{Proserpina}

Quali grazie ti rendo,

Hor che sì nobil dono

Concedi à' prieghi miei signor cortese?

Sia benedetto il dì che pria ti piacqui,

Benedetta la preda e'l dolce inganno,

Poiche per mia ventura,

Feci acquisto di te perdendo il Sole.

\section{Plutone}

Tue soavi parole

D'Amor l'antica piaga

Rinfrescan nel mio core;

Così l'anima tua non sia più vaga

Di celeste diletto,

Sì ch'abbandoni il marital tuo letto.

\section{Coro di Spiriti}

Pietate oggi \& Amore

Trionfan ne l'Inferno.

\section{Spirito}

Ecco il gentil cantore

Che sua sposa conduce al Ciel superno.

\section{Orfeo}

Qual honor di te fia degno,

Mia cetra onnipotente,

S'hai nel Tartareo Regno

Piegar potuto ogni indurata mente?

Luogo havrai tra le più belle

Immagini celesti,

Ond'al tuo suon le stelle

Danzeranno co' giri hor tardi hor presti.

lo per te felice à pieno

Vedrò l'amato volto,

E nel candido seno

De la mia Donna oggi sarò raccolto.

Ma mentre io canto (ohimè) chi m'assicura

Ch'ella mi segua? Ohimè, chi mi nasconde

De l'amate pupille il dolce lume?

Forse d'invidia punte

Le Deita d'Averno,

Perch'io non sia qua giù felice à pieno,

Mi tolgono il mirarvi,

Luci beate e liete,

Che sol col' sguardo altrui bear potete?

Ma che temi, mio core?

Ciò che vieta Pluton comanda Amore.

A Nume più possente

Che vince huomini e Dei

ben ubbidir dovrei

\section{Proserpina}

What thanks may I give you,

Now that so noble a boon

You grant to my prayers, courteous lord?

Blessed be the day that first I pleased you,

Blessed my abduction and the sweet trickery,

Since, to my good fortune,

I won you, losing the Sun.

\section{Plutone}

Your sweet words

Love's ancient wound

Revives in my heart.

Let your soul no more long

For heavenly delight,

Thus to abandon your marriage bed.

\section{Chorus of Spirits}

Pity today, and Love,

Both triumph in Hades.

\section{Spirit}

Here is the gentle singer,

Who leads his bride to the Heaven above.

\section{Orfeo}

What honour is worthy of you,

My all-powerful lyre,

For you have, in the Kingdom of Tartarus,

Been able to make yield every hardened heart?

A place shall you have among the fairest

Images of heaven,

Where at your sound the stars

Shall dance and twirl, now slowly, now quickly.

I, through you, happy at last,

Shall see the beloved face,

And in the white bosom

Of my Lady today I will rest.

But while I sing, alas, who can assure me

That she follows me? Alas, who hides from me

The sweet light of her beloved eyes?

Perhaps, spurred on by envy,

The Gods of Avernus,

So that I should not be happy here below,

Prevent me looking at you,

Blessed and joyful eyes,

That only with a look can bless others?

But what do you fear, my heart?

What Plutone forbids, Love commands.

A mighty God

Who conquers men and Gods

I must obey. 
Qui si fa strepito dietro alla Scena

Ma che odo ohime lasso?

S'arman forse à miei danni

Con tal furor le furie innamorate,

Per rapirmi il mio ben, ed io 'I consento?

Qui si volta

O dolcissimi lumi io pur vi veggio,

lo pur: ma quale Eclissi ohimè v'oscura?

\section{Uno Spirito}

Rott' hai la legge, e se' di grazia indegno

\section{Euridice}

Ahi vista troppo dolce e troppo amara:

Così per troppo amor dunque mi perdi?

Ed io misera perdo

II poter più godere

E di luce e di vita, e perdo insieme

Tè d'ogni ben più caro, o mio Consorte.

\section{Uno Spirito}

Torna a l'ombre di morte,

Infelice EURIDICE,

Ne più sperar di riveder le Stelle,

Ch'ormai fia sordo a' prieghi tuoi I'Inferno.

\section{Orfeo}

Dove te'n vai, mia vita? ecco, io ti seguo,

Ma chi me 'I niega, ohime: sogno o vaneggio?

Qual occulto poter da questi orrori,

Da questi amati orrori

Mal mio grado mi tragge e mi conduce

A l'odiosa luce?

\section{Coro di spiriti}

E' la virtute un raggio

Di celeste bellezza,

Pregio de l'alma ond'ella sol s'apprezza:

Questa di Tempo oltraggio

Non teme, anzi maggiore

Ne l'uom rendono gli anni il suo splendore.

ORFEO vinse l'Inferno, e vinto poi

Fù da gli affetti suoi.

Degno d'eterna gloria

Fia sol colui ch'avrà di sè vittoria.
There is a noise behind the set.

But what do I hear, oh alas?

Perhaps arming themselves with fury, to my loss,

Are the enamored furies,

To take from me what is mine, and I allow it?

Here he turns

O sweetest eyes, I see you now,

I see: But what Eclipse, alas, obscures you?

\section{A Spirit}

You have broken the law, and are unworthy of grace.

\section{Euridice}

Ah, too sweet and too bitter a vision:

So, through too much love, then, do you lose me?

And I, wretched, lose

The power to enjoy more

Light and life, and with them lose

You, dearer than all, O my Consort.

\section{A Spirit}

Return to the shades of death,

Unfortunate EURIDICE,

Nor can you hope to see again the Stars,

For from this moment Hades is deaf to your prayers.

\section{Orfeo}

Where are you going, my life? Lo, I follow you -

But, who stops me, alas: do I dream or rave?

What hidden power of these horrors,

Draws me from these beloved horrors

Against my will, and conducts me

To the hateful light?

\section{Chorus of Spirits}

Virtue is a ray

Of celestial beauty,

Prize of the soul, where alone it is valued:

The ravages of Time

It does not fear, rather

In man do the years restore its greater splendour.

ORFEO conquered Hades and then was conquered

By his emotions.

Worthy of eternal glory

Is the one who will have victory over himself.

Here the set changes again.

Qui di nuovo si volge la Scena. 


\section{ATTO QUINTO}

Orfeo

Questi i campi di Tracia, e quest'è il loco

Dove passommi il core

Per l'amara novella il mio dolore.

Poiche non ho più speme

Di ricovrar pregando,

Piangendo e sospirando,

Il perduto mio bene,

Che poss'io più? se non volgermi à voi,

Selve soavi, un tempo

Conforto a' miei martir, mentre al ciel piacque

Per farvi per pietà meco languire

Al mio languire.

Voi vi doleste, ò Monti, e lagrimaste

Voi sassi al dipartir del nostro Sole,

Ed io con voi lagrimerò mai sempre

E mai sempre dorròmmi, ahi doglia, ahi pianto!

\section{Eco}

Hai pianto.

\section{Orfeo}

Cortese Eco amorosa,

Che sconsolata sei

E consolar mi vuoi ne' dolor miei,

Benchè queste mie luci

Sien già per lagrimar fatte due fonti,

In così grave mia fera sventura

Non hò pianto però tanto che basti.

Eco

Basti.

\section{Orfeo}

Se gli occhi d'Argo havessi

E spandessero tutti un Mar di pianto, Non fora il duol conforme a tanti guai.

\section{Orfeo}

These are the fields of Thrace, and this is the place where my heart was pierced

By grief at the bitter tidings.

Since I have no further hope

To recover through pleading,

Weeping and sighing,

My lost beloved,

What more can I do, if I turn not to you,

Sweet woods, once

Comfort to my suffering, while it pleased heaven

To make you languish with me in your compassion

At my languishing?

You grieved, O Mountains, and you cried,

Rocks, at the leaving of our Sun,

And I will always weep with you

And always will yield myself to grief, like you have weeped!

Echo

You have weeped.

\section{Orfeo}

Gentle, loving Echo,

You who are disconsolate

And would console me in my grief,

Although these my eyes

Through tears become two fountains,

So grievous is my misfortune

I still have not tears enough.

\section{Echo}

Enough.

\section{Orfeo}

If I had the eyes of Argus,

And all poured out a Sea of weeping. Their grief would not match such woe.

Echo

Oh.

Ahi. 


\section{Orfeo}

S'hai del mio mal pietade,

lo ti ringrazio di tua benignitade.

Ma mentr'io mi querelo,

Deh perchè mi rispondi

Sol con gli ultimi accenti?

Rendimi tutti integri i miei lamenti.

Ma tu, anima mia, se mai ritorna

La tua fredd'ombra a queste amiche piaggie,

Prendi da me queste tue lodi estreme.

C'hor à te sacro la mia cetra e 'I canto.

Come à te già sopra l'altar del core

Lo spirto acceso in sacrifizio offersi.

Tu bella fusti e saggia, e in te ripose

Tutte le grazie sue cortese il Cielo,

Mentre ad ogni altra de' suoi don fù scarso.

D'ogni lingua ogni lode a te conviensi,

Ch'albergasti in bel corpo alma più bella,

Fastosa men quanto d'onor più degna.

Or l'altre Donne son superbe e perfide,

Ver chi le adora dispietate instabili,

Prive di senno e d'ogni pensier nobile,

Ond'à ragion opra di lor non lodansi,

Quinci non fia giammai che per vil femina

Amor con aureo strale il cor trafiggami.

\section{Apollo}

(descende in una nuvola cantando)

Perch' a lo sdegno ed al dolor in preda

Così ti doni ò figlio?

Non è, non è consiglio

Di generoso petto

Servir al proprio affetto;

Quinci biasmo e periglio

Già sovrastar ti veggio,

Onde movo dal ciel per darti aita.

Hor tu m'ascolta e n'avrai lode e vita.

\section{Orfeo}

Padre cortese, al maggior uopo arrivi,

Ch'a disperato fine

Con estremo dolore

M'avean condotto già sdegno ed Amore.

Eccomi dunque attento a tue ragioni,

Celeste padre; hor ciò che vuoi m'imponi.

\section{Orfeo}

If you have compassion for my misfortune,

I thank you for your benevolence.

But while I lament,

Why do you answer me

Only with my last words?

Give me back all of my laments.

But you, my soul, if ever there should return

Your cold shade to thes friendly meadows,

Take from me these last praises,

Since now my lyre and song are sacred to you only,

As on the altar of my heart

I offered you my ardent spirit in sacrifice.

You were beautiful and wise, and in you

Kind Heaven rested all its graces,

While it was sparing in its gifts to every other woman.

In every tongue every praise is due to you,

For in your fair body you sheltered a fairer soul,

Lesser in pride, thus the more worthy of honour.

Now other Women are haughty and fickle,

Pitiless and changeable to their adorers,

Without judgment and noble thoughts,

Whence rightly their behavior is not praised.

Therefore may it never be that, for a worthless woman,

Love with his golden arrow pierces my heart.

\section{Apollo}

(descending on a cloud, singing)

Why, a prey to anger and grief,

Do you so freely give yourself, $\mathrm{O}$ son?

It is not, it is not the wisdom

Of a generous heart

To serve its own affliction.

Since with blame and danger

Already I see you overcome,

I come from heaven to give you aid.

Now listen to me and you shall have glory and life.

\section{Orfeo}

Kind father, you come when I am in need,

When to a desperate end

With extreme grief

Anger and Love has already brought me.

Here I am then, attentive to your counsels,

Heavenly father, now command me as you want.

Please turn page quietly 


\section{Apollo}

Troppo, troppo gioisti

Di tua lieta ventura;

Hor troppo piagni

Tua sorte acerba e dura.

Ancor non sai

Come nulla qua giù diletta e dura?

Dunque se goder brami immortal vita,

Vientene meco al Ciel, ch'a se t'invita.

\section{Orfeo}

Si non vedrò più mai

De l'amata EURIDICE i dolci rai?

\section{Apollo}

Nel sole e nelle stelle

Vagheggerai le sue sembianze belle

\section{Orfeo}

Ben di cotanto Padre sarei non degno figlio

Se non seguisci il tuo fedel consiglio

\section{Apollo ed Orfeo}

(assende al Cielo cantando)

Saliam cantando al Cielo,

Dove ha virtù verace

Degno premio di sè, diletto e pace.

\section{II fino del quinto Atto}

\section{Coro}

Vanne, ORFEO, felice apieno

A goder celeste honore

L'ave ben non mai vien meno.

L'ave mai non fu dolore,

Mentr'altari, incensi e voti

Noi t'offriam lieti e devoti.

Così va chi non s'arretra

Al chiamar di lume eterno,

Così grazia in ciel impetra

Ahi qua giù provò l'inferno

E chi semina fra doglie

D'ogni grazia il frutto coglie.
Apollo

Too much, too much did you rejoice

In your happy fate,

Now too much do you weep

At your bitter, hard fortune.

Do you still not know

How nothing that delights down here will last?

Therefore, if you want to enjoy immortal life,

Come with me to Heaven, which invites you.

\section{Orfeo}

Shall I never again see

The sweet eyes of my beloved EURIDICE?

\section{Apollo}

In the sun and in the stars

You shall gaze at her fair image.

\section{Orfeo}

Of such a good Father I would not be a worthy son

If I did not follow your trustworthy advice.

Apollo and Orfeo

(ascending to Heaven, singing)

Let us rise, singing, to Heaven,

Where true virtue

Has the due reward of delight and peace.

The end of Act five.

\section{Chorus}

Go, ORFEO, happy at last, To enjoy celestial honour

Where good never lessens,

Where there was never grief,

While altars, incenses and prayers

We offer to you, happy and devoted.

So goes one who does not retreat

At the call of the eternal light,

So he obtains grace in heaven

Who down here has braved Hell

And he who sows in sorrow

Reaps the fruit of all grace. 